\title{
Ecology and distribution of ostracods in Kuwait Bay
}

\author{
S. AL-ABDUL-RAZZAQ**, W. SHUBLAQ + , Z. AL-SHEIKH* \& W. KITTANEH* \\ * Department of Geology, Kuwait University, P.O. Box 5959, Safat, Kuwait. \\ $\dagger$ Kuwait Institute for Scientific Research, P.O. Box 24885, Safat, Kuwait.
}

\begin{abstract}
Few ostracods live in the central part of Kuwait Bay due to the effect of ebb and flow currents in the central channel. The number increases gradually towards the nearshore areas and then decreases rapidly near the tidal flat areas due to turbidity in the northeastern zone and pollution in Sulaibikhat Bay. Different ostracod assemblages inhabit the subenvironments of the bay. The tidal-flat assemblage differs from that of the nearshore area and from the assemblage living in the restricted area in the western corner of the bay. Ostracods in the bay are mostly found living on clayey silt sediments and sandy mud.

Forty-nine species belonging to 39 genera were recognised in the bay, of which 28 were found living there. The dominant living species in the bay include Hemicytheridea paiki Jain, 1978; Keijella nealei Jain, 1978; Jainella karwarensis Bhatia \& Kumar, 1979; Propontocypris $\mathrm{sp}$.; Chrysocythere keiji Jain, 1978; Aglaiocypris sp.; Alocopocythere reticulata indoaustralica (Hartmann, 1978); Carinocythereis batei Jain, 1978; Cytherella pulchra Brady, 1868; Hemikrithe peterseini Jain, 1978 and Neomonoceratina sp. cf. N. delicata Ishizaki \& Kato, 1976.
\end{abstract}

\section{INTRODUCTION}

Kuwait Bay is a small, V-shaped embayment in the northwestern part of the Arabian Gulf. The gulf is a marginal sea measuring about $1000 \mathrm{~km}$ in length and 200 to $300 \mathrm{~km}$ in width. The average depth is $35 \mathrm{~m}$, and the maximum depth near its entrance at the Strait of Hormuz is $100 \mathrm{~m}$. The Strait of Hormuz is $60 \mathrm{~km}$ wide, connecting the gulf with the Gulf of Oman and the Indian Ocean. The long axis of the gulf basin separates two distinct morphological provinces whose character is related closely to contrasting tectonic styles on each side. The floor on the more stable Arabian side slopes gently towards the bathymetric axis, while the tectonically unstable Iranian side of the basin is relatively steep (Purser \& Seibold, 1973).

Few publications have discussed the ecology of living marine ostracods in Kuwait Bay or other Kuwaiti waters. The only existing published work is that of Al-Abdul-Razzaq et al. (1982) on Sulaibikhat Bay. This is also true of studies of the ostracods in the Arabian Gulf in general; the only works available are those of Bate (1971), Bate \& Gurney (1981), Bate \& Sheppard (1980) and Paik (1977), on the southwestern and eastern parts of the gulf respectively. Sedimentation, climatic and environmental factors, as well as physical and chemical oceanographic parameters, have been discussed by Al-Abdul-Razzaq et al. (1982), Enomoto (1971), Jacob et al. (1979, 1980a, 1980b) Khalaf et al. (1982), Mohammad (1978), Mohammad \& AlShamlan (1977), and Yamazi (1974). These aspects have also been discussed in the technical reports of Al-
Abdul-Razzaq (1979, 1980), Anderlini (1979), Babtti et al. (1979), Hayes (1977), Jacob et al. (1981), Khalaf et. al. (1979, 1981), and PPAL (1974).

The present study is part of the Marine Pollution Environmental Assessment Program (MPEA) carried out at Kuwait Institute for Scientific Research (KISR). This paper intends to fill the gap in ecological works in Kuwaiti waters and throw light on the ecology and distribution of ostracods in Kuwait Bay.

\section{METHODS}

The Kuwait Bay survey was carried out by staff members of MPEA Programme using the ship R.V. ABATH and a small boat. Ninety bottom sediment samples were collected from the bay (Fig. 1) using a Van Veen grab. Samples were collected on six cruises from 3:12:79 to $5: 5: 80$.

In the laboratory, living ostracods were picked from wet samples or stored frozen (in $70 \%$ ethanol solution) and later studied after the addition of Sudan Black B. The samples were washed under a jet of fresh water in a 200 mesh sieve and dried in an oven at $80^{\circ} \mathrm{C}$. The dried residue was then sieved into five fractions and stored in vials. Ostracod specimens were separated from the sediments by flotation and hand picking. The latter procedure was necessary for separated valves.

\section{ECOLOGY}

Kuwait Bay is a small embayment with an average length of $35 \mathrm{~km}$ and average width of $20 \mathrm{~km}$ (Fig. 1). It is shallow and the bottom surface is generally flat and 


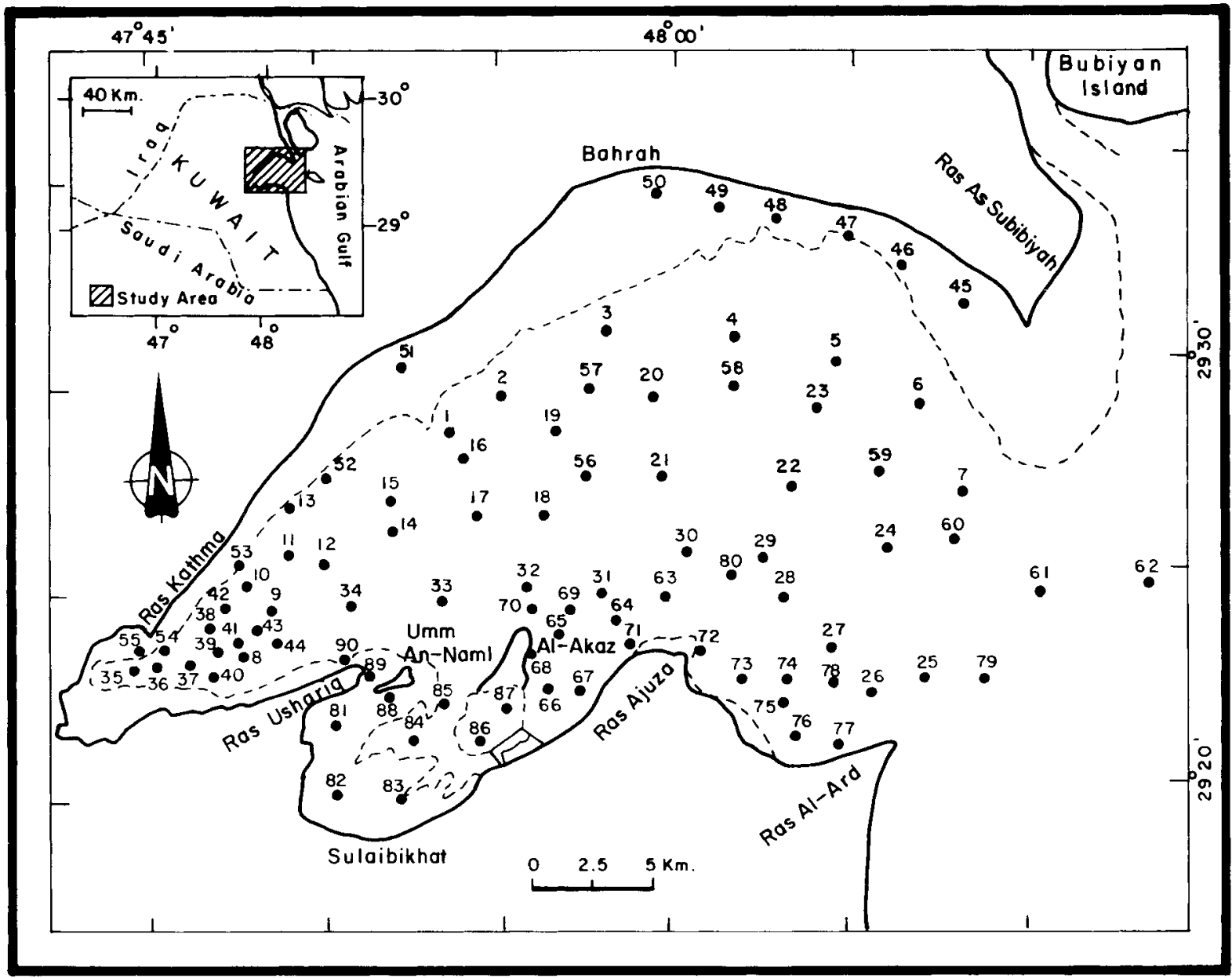

Fig. 1. Location and sampling map of Kuwait Bay.

gradually slopes towards its centre and out towards Ral $\mathrm{Al}$-Ard where the bay is deepest $(28 \mathrm{~km})$. Khalaf ( 1979 , Fig. 7) considered the bay, with the exception of the deeper parts which lie within Kuwait Bay trough, to be part of the submerged estuarine flat, a shallow, muddy area extending from the northern part of the Arabian Gulf south of Faylakkah Island and west in the bay.

Physical and chemical oceanographic data on the bay were collected through the Oceanographic Project of the MPEA Programme (Jacob et al., 1981). All data used in this study are from this project unless stated otherwise.

The sediment distribution in the bay is as follows: the tidal zone extending from Ras As Subbiyah to Ras Kathma, as well as the tidal flat area of Sulaibikhat Bay, has a silt substrata. The area extending from Ras $\mathrm{Al}$-Ard to Ras Ajuza westward to around $\mathrm{Al}$-Akaz tidal flat and Umm An-Namel Island as well as Doha headland to Khuwaisat contains a mixture of sand, muddy sand, and sandy mud sediments. Rocky-bottom surfaces occur near Ras Al-Ardh at a depth of 25 to 28 metres, as well as near the coastline of Ras Ajuza, near the Shuwaikh port, around Al-Qurain (Al-Akaz) and Umm-AnNamel islands and the Doha coastline. The centre of the bay contains silty clay which is surrounded by clayey silt covering more than $50 \%$ of the bay (Fig. 3).

Living ostracods in Kuwait Bay occur in different types of bottom sediments. They are most abundant in clayey silt and sandy mud; their numbers decrease in silty clay, sand, silt and muddy sand respectively. In the sandy bottom areas the ratio of carapaces to valves is more than 1 ; usually between about 2.1 and 7.1 . The ratio decreases in sandy silt, silt, and sandy mud samples, where it lies between 0.1 and 0.9 .

The surface water temperature of the bay ranges between $14.7^{\circ} \mathrm{C}$ during January and $27.4^{\circ} \mathrm{C}$ during May. Little difference was recorded between surface and bottom temperature, about 0.5 to $1.5^{\circ} \mathrm{C}$ due to the shallowness of the bay. The highest temperatures are during August $\left(30-37^{\circ} \mathrm{C}\right)$ (Enomoto, 1971). 
Jacob et al. (1981) recorded an average salinity of $41.8 \%$ oo during December, whereas Moharnmad (1978) found that salinity increased rapidly from the northwestern $(40 \%)$ to the southern and southwestern parts of the Bay $\left(52^{\circ} \%\right)$.

Dissolved oxygen in the bay waters ranges between 7 and $7.9 \mathrm{mg} / \mathrm{l}$ in most localities, except near Ras AsSubbiyah where it increases to 8.2 and $8.3 \mathrm{mg} / \mathrm{l}$. These values, however, decrease near Sulaibikhat Bay (4 to 5 $\mathrm{mg} / \mathrm{l}$ ), probably due to the increase of the total organic carbon (T.O.C.) in this area making the consumption of oxygen higher. The highest dissolved oxygen content in the bay is at its entrance $(8.7 \mathrm{mg} / \mathrm{l})$ at station $62 \mathrm{~A}$. Khalaf et al. (1981) showed that T.O.C. in the bay ranged between $0.46 \%$ to $2.0 \%$, with the highest percentages near the southern coast of the bay, especially in Sulaibikhat Bay and decreasing northwards.

PH values in the bay remain almost constant with an average of 8.3 during the months of December and May, although the southern part (Sulaibikhat Bay) has higher values (8.5 to 8.6). Andrews et al. (1972) indicated that a $\mathrm{pH}$ range of 6.7 to 8.6 will support a good fish population, and very few species tolerate a $\mathrm{pH}$ beyond this range. The extreme $\mathrm{pH}$ values in Sulaibikhat Bay are not as expected since the high organic content and high rate of organic decomposition generally result in acid waters. Extreme $\mathrm{pH}$ values are therefore taken to represent pollution; in Sulaibikhat Bay this takes the form of the dumping of alkaline materials and release of constructional wastes into the bay (see Al-AbdulRazzaq et al., 1982).

Turbidity of the water is affected by the northwestern (shamal) winds and the monsoon winds, as well as water depth and currents. In general, turbidity is $6.8 \mathrm{ppm}$ with the exception of the northern coastal area, where the turbidity increases to an average of $25 \mathrm{ppm}$ due to the effects of extreme shallowness and the currents in this area.

Living ostracods in Kuwait Bay were abundant except in the tidal flat areas and the central channel (Fig. 2).

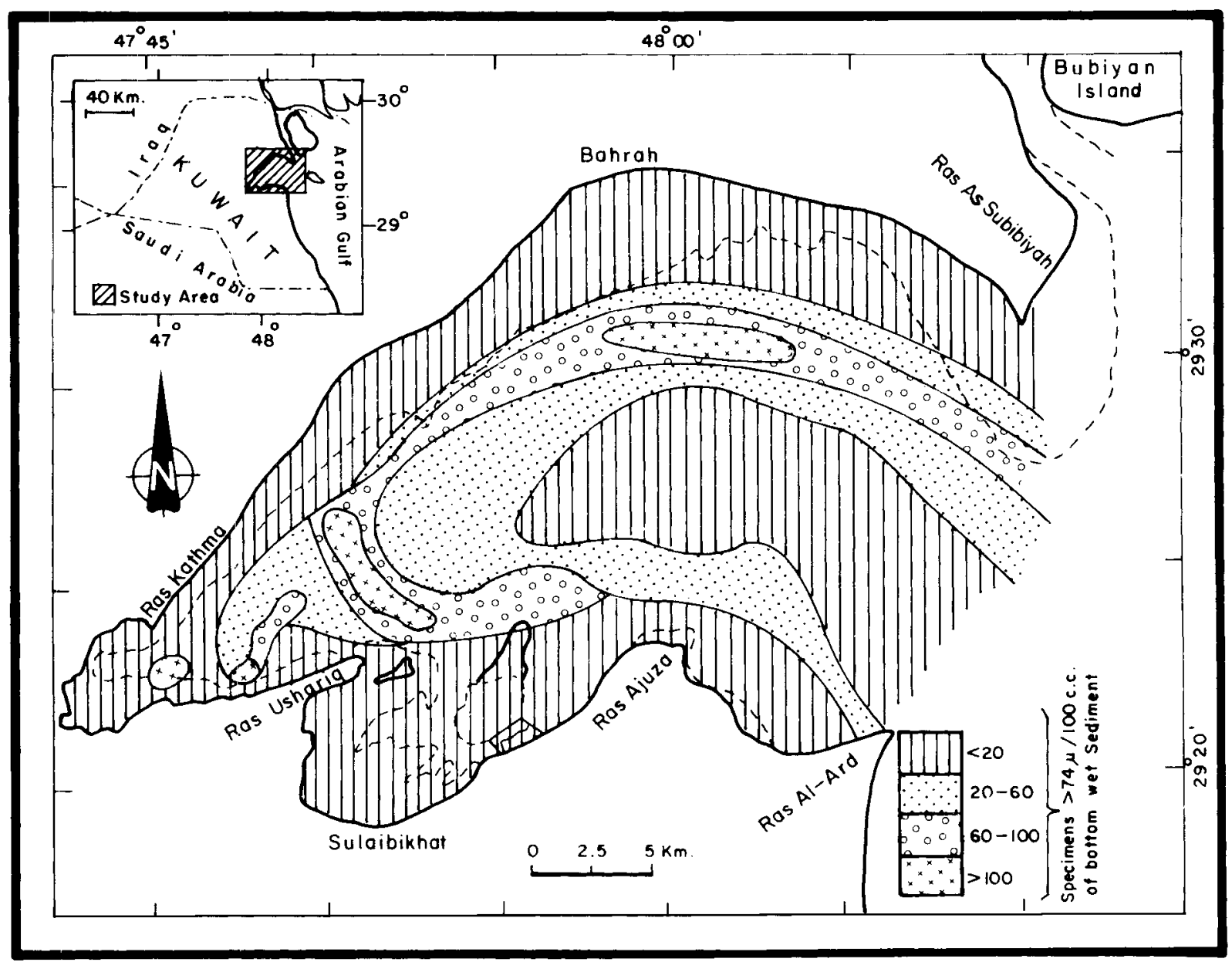

Fig. 2. A biofacies map showing the abundance of living ostracods (as a whole) in Kuwait Bay. 


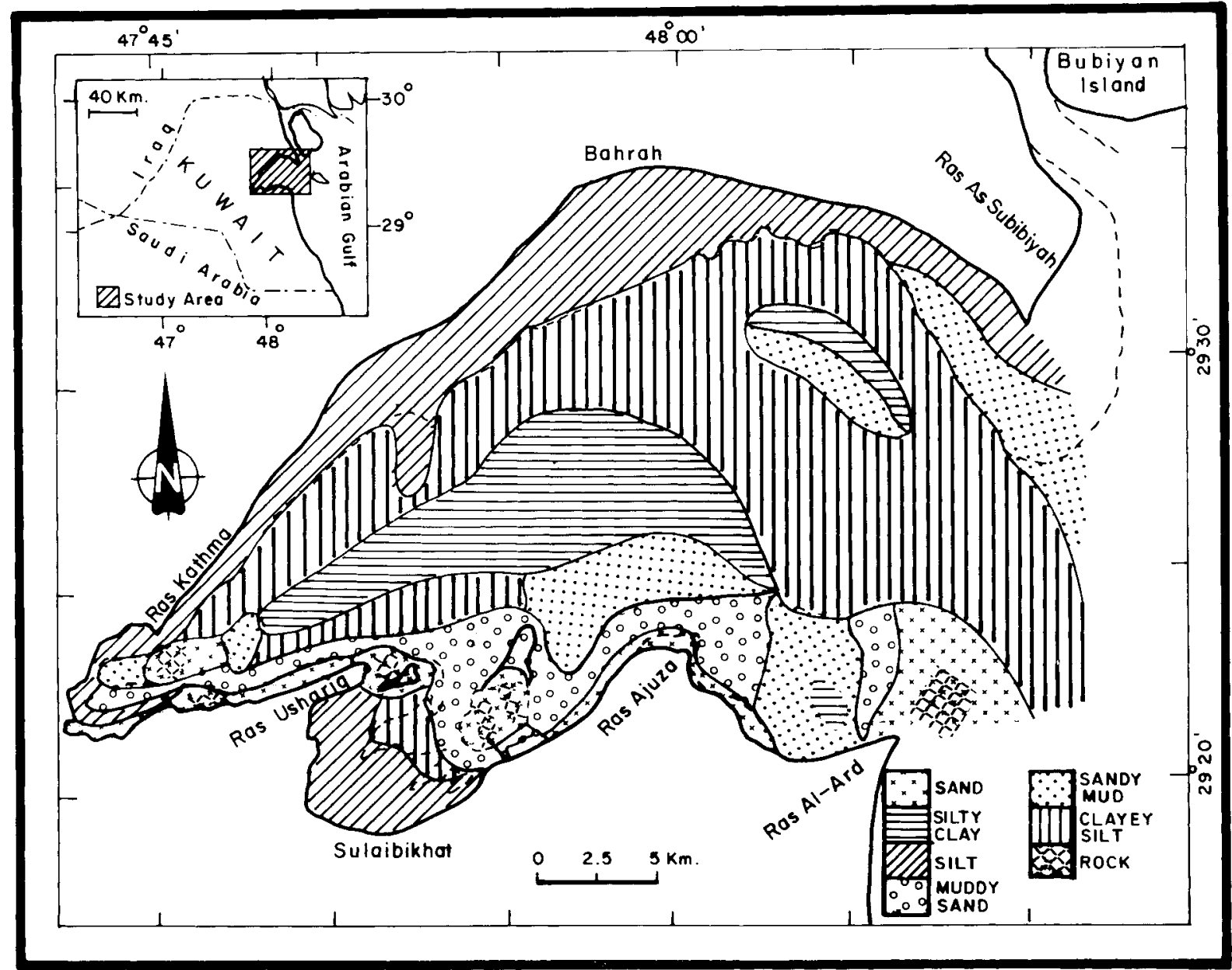

Fig. 3. A lithofacies map showing distribution of sediments in Kuwait Bay.

Few ostracods live in the central part of the bay, although the area is covered with silty clay and the physical and oceanographic parameters have average values, due to the effect of tidal currents through the central channel of the bay. The number of living ostracods increases gradually towards the nearshore areas, which are covered with silty clay sediments. The distribution is also true of dead ostracod specimens (Fig. 3). All the physical and oceanographic controlling factors in the nearshore areas are average compared to the rest of the bay.

Living ostracod numbers decrease towards the tidal flats of the bay, where turbidity seems to be the most important controlling factor in the northeastern tidal flat zone while high salinity, temperature, T.O.C. and $\mathrm{pH}$, low dissolved oxygen content and pollution are the controlling factors in Sulaibikhat Bay area (see AlAbdul-Razzaq, et al. 1982). The number of dead specimens continues to increase both towards the north and the south and reaches a maximum near Ras AsSubbiyah due to the effect of currents in the bay. The low number of ostracods in Sulaibikhat Bay is influenced by tidal currents within this small bay.
Forty-nine ostracod species belonging to 39 genera have been recognised in the bottom sediments of Kuwait Bay; of these 28 species were found living in the bay, see Table 1. The dominant living ostracods in the bay are Hemicytheridea paiki Jain, 1978; Keijella nealei Jain, 1978; Jainella karwarensis Bhatia \& Kumar, 1979; Propontocypris sp.; Chrysocythere keiji Jain, 1978; Aglaiocypris sp.; Alocopocythere reticulata indoaustralica (Hartmann, 1978); Carinocythereis batei Jain, 1978; Cytherella pulchra Brady, 1866; Hemikrithe peterseini Jain, 1978; Neomonoceratina sp. cf. $N$. delicata Ishizaki \& Kato, 1976.

Certain ostracods are found living only in certain restricted areas, such as the western corner of Kuwait Bay near Ras Kathma, particularly around stations 35 , 37,39 and 40 . The Ras Kathma assemblage is found living in shallow, sandy bottom sediments about 3 to $5 \mathrm{~m}$ depth; this comprises Cushmanidea guhai Jain, 1978; Rutiderma irrostratum Kornicker \& Caraion, 1978; Callistocythere sp. cf. C. flavidofusca intricatoides (Ruggieri, 1953); Sarsiella sp.; and Microasteropteron $\mathrm{sp}$. The former three species were originally described 
Table 1. A List of ostracod species found in Kuwait Bay

\begin{tabular}{|c|c|c|c|}
\hline 1. & Actinocythereis sp. & 26. & Loxoconcha (L.) indica* Jain, 1978 \\
\hline 2. & Aglaiocypris sp* & 27. & Loxoconcha (L.) amygdalanux* Bate \& \\
\hline 3. & Alocopocythere reticulata & & Gurney, 1981 \\
\hline 4. & $\begin{array}{l}\text { indoaustralica* Hartmann } 1978 \\
\text { Atjehella sp. aff. A. semiplicata }\end{array}$ & 28. & $\begin{array}{l}\text { Loxoconcha (L.) multiornata* Bate \& } \\
\text { Gurney, } 1981\end{array}$ \\
\hline & Kingma (1948) & 29. & Loxoconcha (E.) batei* Bate \& \\
\hline 5. & Bradleya sp. & & Gurney, 1981 \\
\hline 6. & Bythocertina sp. & 30 . & Loxoconcha sp. 5 \\
\hline 7. & Callistocythere cf. flavidofusca & 31. & Microasteropteron* ${ }^{*} \mathrm{sp}$ \\
\hline 8. & $\begin{array}{l}\text { intricatoides* (Ruggieri), } 1953 \\
\text { Caudites sp. }\end{array}$ & 32. & $\begin{array}{l}\text { Mutilus splendideornatus } \\
\text { australliensis, Hartmann, } 1978\end{array}$ \\
\hline 9. & Carinocythereis batei* Jain, 1978 & 33. & Neomonoceratina sp. 1 \\
\hline 10. & Carinocythereis cf. hamata* & 34. & Neomonoceratina sp. 2 \\
\hline & (Kingma, 1948) & 35. & Neomonoceratina delicata* \\
\hline 11. & Carinocythereis cf. indica* Jain, 1978 & & Ishizaki and Kato, 1976 \\
\hline 12. & Chrysocythere keiji* Jain, 1978 & 36. & Paijenborchellina sp. \\
\hline 13. & Cushmanidea guhai* Jain, 1978 & 37. & Paracytheridea sp. \\
\hline 14. & Cythere spp: & 38. & Paracytherois sp. \\
\hline 15. & Cytherella pulchra* Brady, 1866 & 39. & Propontocypris $\mathrm{sp}^{*}$ \\
\hline 16. & Cytherelloide'a sp. & 40 & Ruggieria (K) sp. \\
\hline 17. & Cytheroma dimorpha* Hartmann, 1964 & 41. & Ruggieria $(R)$ darwini Brady, 1968 \\
\hline 18. & Hemicytheridea paiki* Jain, 1978 & 42. & Rutiderma irrostratum* \\
\hline 19. & Hemicytherura? videns & & Kornicher \& Caraion, 1978 \\
\hline 20 , & Hemikrithe peterseini ${ }^{*}$ Jain, 1978 & 43 . & Sarsiella $\mathrm{sp}^{*}$ \\
\hline & $\begin{array}{l}\text { Jainella karwarensis } * \text { Bhatia and } \\
\text { Kumar, } 1979\end{array}$ & $\begin{array}{l}44 . \\
45 .\end{array}$ & $\begin{array}{l}\text { Semicytherura sp. } \\
\text { Tanella cf. gracilis* Kingma, } 1948\end{array}$ \\
\hline 22. & Keijella neale ${ }^{*}$ Jain, 1978 & 46. & Triebelina sp. \\
\hline & Krithe kroemmelbeini Jain, 1978 & 47. & Thalmania sp. \\
\hline 24. & $\begin{array}{l}\text { Leguminocythereis papuensis } \\
\text { (Brady, 1880) }\end{array}$ & 48. & $\begin{array}{l}\text { Xestoleberis rhomboidea } \\
\text { Hartmann, } 1964\end{array}$ \\
\hline 25. & Leptocythere $\mathrm{sp}^{*}$ & 49. & Xestoleberis rotunda* Hartmann, 1964 \\
\hline
\end{tabular}

from shallow waters; it is not clear whether this restricted western area of the Bay is a true habitat for these species.

The dominant species of the tidal flat zone of Sulaibikhat Bay (H. paiki; Loxoconcha (L.) indica Jain, 1978; Xestoleberis rotunda Hartmann, 1964; X. rhomboidea Hartmann, 1964; and Tanella gracillis Kingma, 1948, see Al-Abdul-Razzaq, et al., 1982) are not found in Kuwait Bay with the exception of $H$. paiki. This species shows no special preference for a particular environment and has a wide range of tolerance to salinity and temperature. Living specimens of $H$. paiki were reported in almost all the samples studied in the bay; these were the only living specimens found in the tidal flat zone of Ras As-Subbiyah. Individuals of $H$. paiki were found living after storage in a refrigerator at a temperature of about 4 to $5^{\circ} \mathrm{C}$ for 20 days.
Loxoconcha $(L$.$) indica, X$. rotunda, and $X$, rhomboidea are restricted to the tidal flat zone of Sulaibikhat Bay, the only area in Kuwaiti waters where these species are found living. Bate \& Gurney (1981) indicated that Loxoconcha $(L$.) indica is restricted solely to a lagoon environment in the Abu Dhabi area in the Arabian Gulf.

\section{DISTRIBUTION}

Most of the dominant ostracods living in Kuwait Bay also occur in the Arabian Sea along the western coast of India; $H$. paiki, A. reticulata indoaustralica, C. keiji, $H$. peterseni, C. batei, J. karwarensis, K. nealei, N. cf. delicata, C. guhai, and C. flavidofusca itricatoides. It is considered that these species migrated to the gulf from the Indian Ocean.

$H$. paiki has been found not only in the tidal-flat zone, the lagoonal areas, and nearshore areas of Kuwait Bay, 
the Arabian Gulf, and Indian Ocean (Paik, 1977; Jain, 1978 ), but also from deep areas (94 to about $200 \mathrm{~m}$ ) from the Gulf of Oman (Paik, 1977). Although this species is the dominant one in Kuwaiti waters, it was not recorded by Bate (1971) from the Abu Dhabi lagoonal area, southwest of the Arabian Gulf.

Hartmann (1978) indicated that $A$. reticulata, found in the Red Sea area, is different from $A$. reticulata indoaustralica. The latter subspecies, which is most abundant in the northeastern parts of the bay and the north of Ras Ajuza, is an Indopacific form found in western Australia (Hartmann, 1978), the west coast of India (Jain, 1978; Bhatia \& Kumar, 1979), the Gulf of Oman (Paik, 1977), and the Arabian Gulf (Bate, 1971; Paik 1977). Paik (1977) indicated that this species is widespread in the eastern side of the Arabian Gulf and is characteristic of shallow water down to $200 \mathrm{~m}$. The other Indopacific species found in the gulf and the Arabian Sea are $N$. sp. cf. $N$. delicata and $T$. sp. cf. $T$. gracilis (Bate, 1971; Paik, 1977; Jain, 1978; Hartmann, 1978; Bhatia \& Kumar, 1979). The former species was abundant in many samples from the northeastern parts of the bay.

C. kaiji, H. peterseini, J. karwarensis, and C. guhai have their maximum distribution in the shallow waters of Kuwait Bay and the Iranian coast of the Arabian Gulf. Paik, (1977) found these species most commonly in areas less than $22 \mathrm{~m}$ deep. These species were also recorded from the Arabian Sea (Jain, 1978; Bhatia \& Kumar, 1979). J. karwarensis was also recorded from the southern coast of India and Abu Dhabi lagoon by Paik (1977) and Bate (1971) respectively.

$K$. nealei and $C$. sp. cf. C. flavidofusca intricatoides were most abundant in the 22 to $94 \mathrm{~m}$ deep zone that covers most of the Arabian Gulf in and, for K. nealei, the Gulf of Oman as well (Paik, 1977). These species were also recorded from the Arabian Sea (Jain, 1978) and the Mediterranean Sea, Ruggieri, (1953).

The only species found in Kuwait Bay and the Red Sea are $X$. rotund $a$ and $X$. rhomboidea (see Al-AbdulRazzaq, et al., 1982 and Bate, 1971).

\section{ACKNOWLEDGMENTS}

We thank F. Khalaf E. \& E.S. Division Director, KISR, for his help and assistance throughout the course of this work and V. Anderlini of KISR for supervising the collection of oceanographic data. Special thanks are extended to G. Hartmann, S.P. Jain, L.S. Kornicker and S.B. Bhatia for checking the ostracods identified from Kuwait Bay.

This study was supported by the Kuwait Institute for Scientific Research, Marine Sedimentary Benthic Ecology Project, EES-11D.

\section{REFERENCES}

Al-Abdul-Razzaq, S., Shublaq, W. \& Z. 1979. A preliminary investigation of the marine benthic microfauna of Kuwait M.P.E.A.P., E. \& E.S. Div. Interim Report. KISR/PPI 183 / EES-RT-R-7915, $91 \mathrm{pp}$.

Al-Abdul-Razzaq, S., Shublay, W., Al-Sheikh, Z. \& Kittaneh, W. 1980. Marine benthic microfauna of the Kuwait Bay, Kuwait, Arabian Gulf. M.P.E.A.P., E. \& E.S. Div. Interim Report, KISR 123, 207 pp

Al-Abdul-Razzaq, S., Shublaq, W., \& Al-Sheikh, Z. 1982. Ostracode distribution and ecology of the Sulaibikhat Bay. Mar. Geol., 47, 57-75.

Anderlini, V. 1979. Oceanographic observation for Kuwait. KISR/PPI 195/EES-RT-R-7919, 35 pp.

Andrews, W., Moore, D., \& Le Roy, A. 1972. Environmental pollution. 266 pp., Prentice-Hall of Canada Ltd., Scarborough, Ontario.

Babtie, Shaw, \& Morton. 1979. Development of Sulaibikhat Bay. 46 pp. A report study by Consulting Civil and Structural Engineers, Ministry of Public Works, Kuwait.

Bate, R.H. 1971. The distribution of Recent Ostracoda in the Abu Dhabi Lagoon, Persian Gulf. Colloque Pau (1970) Bull. Centre Rech. Pau-SNPA suppl. 5, 239-256.

Bate, R.H. \& Gurney, A. 1981: The ostracod genus Loxoconcha Sars from Abu Dhabi lagoon and the neighbouring near-shore shelf, Persian Gulf. Bull. Br. Mus. nat. Hist., London, (Zool.). 41, 235-251.

Bate, R.H. \& Sheppard, L.M. 1980. On Xestoleberis postangulata Bate \& Sheppard sp. nov. Stereo-Atlas Ostracod Shells, 7, 101-106.

Bhatia, S.B. \& Kumar, S. 1979. Recent ostracodes from off Karwar, west coast of India. 7th Int. Symp. on Ostracodes, Belgrade, pp. 17I-178.

Enomoto, Y. 1971. Oceanographic survey and biological study of shrimps in the water adjacent to the eastern coasts of the State of Kuwait. Bull. Takai Reg. Fish. Res. Lab, , 66, 1-44.

Hartmann, G. 1964. Zur Kenntnis der Ostracoden der Roten Meeres. Kieler Meeresforsch., 20, 35-127.

Hartmann, G. 1978. Dei Ostracoden der Ordnung Podocopida G.W. Muller, 1894 der tropisch-subtrepischen Westkuste Australiens (Zwischen Kerby im Norden und Perth in Suden). Mitt. Hamb. Zool. Mus. Inst., 75, 64-219.

Hayes, M.O. 1977. Preliminary investigation of the coastal processes of Sulaibikhat Bay, Kuwait. 51 pp. Feasibility Study by Sosaki Associates Inc. Cons., U.S. A. with G. Sultan and K.E.O., Ministry of Public Works, Kuwait.

Jain, S.P. 1978. Recent Ostracoda from Mandvi Beach, west coast of India. Bull. Ind. Geol. Assoc., 11, 89-139.

Jacob, P.G., Zarba, M.A.\& Anderlini, V. 1979. Hydrography, chlorophyll and plankton of the Kuwaiti coastal waters Indian J. Mar. Sci., 8, 150-154.

Jacob, P.G., Zarba, M.A.\& Anderlini, V. 1980a. Observations on the plankton and hydrography of the Kuwaiti waters. Mahasagar Bull. Nat. Inst. Ocean., 13 (4), 325-334.

Jacob, P.G., Zarba, M.A.\& Anderlini, V. 1980b. Biochemical and related features of benthic mud of Kuwaiti waters. Indian J. Mar. Sci., 9, 100-105.

Jacob, P.G., Zarba, M.A. \& Anderlini, V. 1981. Physical and chemical occanography of Kuwait Coastal waters (From December 1979 to May 1980). EES-11F, KISR $168,70 \mathrm{pp}$.

Khalaf, F., Saleh, S.A., Al-Modyain, L. \& Omran, L. 1979 Preliminary sedimentological investigation of the Marine bottom sediments of Kuwait. M.P.E.A.P., E. \& E.S. Div. Interim Report, KISR/PPI 152/EES-RT-R-7911, pp. 1-85. 
Khalaf, F., Saleh, S.A., Al-Ghadban, A., Eid, A. \& AlModyain, L. 1981. Sedimentology and mineralogy of Kuwait Bay bottom sediments. E. \& E.S.D. Interim Report. EES-11E, KISR 175, 140 pp.

Khalaf, F., Al-Ghadban, A., Al-Saleh, S. \& Ail-Omran, L. 1982. Sedimentology and mineralogy of Kuwait Bay bottom sediments. Kuwait - Arabian Gulf Mar. Geol., 46, 71-99.

Kingma, J.T. 1948. Contributions to the knowledge of the young Genoroic ostracode from the Malayan region. $118 \mathrm{pp}$. Proefschrift, Utrecht.

Kornicker, L.S. \& Caraion, F.E. 1978. West African Myodocopid Ostracoda (Sarsiellidae, Rutidermatidae). Smith. Contr. Zool., 250, 1-110.

Mohamad, M. 1978. Preliminary marine geological studies on recent sediments of Kuwait Bay. Jour. Univ. Kuwait (Sci.)., 5, 161-178.

Mohammad, M.A.\& Al-Shamlan, A.A. 1977. Organic matter content in Kuwait Bay sediments as an index of pollution. Jour. Univ. Kuwait (Sci.)., 4, 215-222.

Paik, H.K. 1977. Regionale Untersuchungen zur Verteilung der Ostracoden im Persischen Golf und im Golf Von Oman. "Meteor" Forsch. Ergebnisse, Reihe C, 28, 37-76.

Project Planning Assoc. Ltd. 1974. Feasibility study, Sulaibikhat Bay. Ministry of Public Works, Kuwait, 139 pp.

Purser, B.H., \& Seibold, E. 1973. The principal environmental factors influencing Holocene sedimentation and diagenesis in the Persian Gulf. In Purser, B.H. (Ed.), The Persian Gulf, $1-10$., Springe-Verlag, New York.

Rugieri, G. 1953. Eta fauna di un terrazo marino dulla costa ionica della Giorno Geol. Ser. 2A. 23, 19-168.

Yamazi, I. 1974. Analysis of the data on temperature, salinity and chemical properties of the surface water, and the zooplankton communities in the Arabian Gulf in December, 1968. In Kuronuma, K. (Ed.), Arabian Gulf FisheryOceanography Survey, Trans. Tokyo University Fish., No. I, $118 \mathrm{pp}$. 